\title{
IMPORTANCE OF THE EXERCISE TEST FOLLOW-UP PROGRAMME FOR PATIENTS WITH CORONARY ARTERY DISEASE WHO UNDERWENT PERCUTANEOUS CORONARY INTERVENTION
}

\author{
Iveta Mintāle, Inga Narbute, Sanda Jēgere, Milāna Zabunova, Dace Lūriṇa, \\ I!ja Zakke, Vilnis Taluts Dzērve, and Andrejs Ërglis \\ Latvian Centre of Cardiology, Pauls Stradinš Clinical University Hospital, Pilsonu iela 13, Rīga, LV-1006, LATVIA \\ E-mail: iveta@stradini.Iv
}

Contributed by Andrejs Ërglis

\begin{abstract}
The clinical course and prognosis of coronary heart disease (CHD) can be modified favourably with percutaneous coronary intervention (PCl) in combination with medication. A follow-up programme was developed in the Latvian Centre of Cardiology, which included a stress electrocardiogram for patients after $\mathrm{PCl}$. This is the first study in Latvia, and provides wide opportunities to evaluate functional status of patients, treatment effectiveness, possible risks and prognosis after $\mathrm{PCl}$. Exercise tests are widely used for the evaluation and diagnostics of CHD. This method has been successfully implemented in diagnostics of restenosis in coronary arteries, a process which pathophysiologically differs from primary atherosclerosis. A total of 7,300 patients with $\mathrm{CHD}$ were followed-up in one year after PCl. An exercise test was conducted one, three, six and twelve months after PCl. Clinical and functional status of patients and risk of restenosis were evaluated and corrections in medications were made. Seventeen percent of patients had chest pain and $13 \%$ had significant ST-segment changes in electrocardiogram. Restenosis of coronary arteries in angiography were established in $6.4 \%$. In half of those patients above restenosis was diagnosed early - three to six months after PCl. We established a patient subgroup (22\%) with "silent" ischemia (positive exercise test without chest pain), out of whom $41 \%$ had restenosis. For left main (LM) disease patients $50 \%$ of all restenosis diagnoses also were diagnosed early (three to six month after $\mathrm{PCl}$ ). Restenosis was associated with ST-segment deviation in the exercise electrocardiogram. A lower Robinson index (RI) was registered in the same group of patients. A focussed follow-up programme performing exercise test allows to determine timely possible risk of restenosis, to adapt medication doses, to reduce risk factors and to influence positively patients' compliance.
\end{abstract}

Key words: coronary heart disease, percutaneous coronary intervention, restenosis, exercise test.

\section{INTRODUCTION}

In Latvia, there is a heavy burden of coronary heart disease (CHD), which still remains the leading cause of death in our country. Priority is given to patients with established CHD because they are at high risk of further cardiovascular morbidity and mortality (Fletcher et al., 1995). CHD management consists of interventional as well as therapeutic treatment. Since the implementation of interventional treatment restenosis appeared as a new challenge for cardiologists. Restenosis pathophysiologically differs from primary atherosclerosis (backward contraction, late remodulation, thrombosis, neointimal proliferation), which makes it competitive for cardiovascular diagnostics (Libby and Theroux, 2005). Only one-third of patients with restenosis have typi- cal complaints like angina pectoris under physical exercise. Almost half of the patients with restenosis have asymptomatic ST-segment changes in electrocardiogram during physical test (silent ischemia) (Bengston et al., 1990; Ruygrok et al., 2001). Those patients have very high risk of coronary events, which adds special importance to early diagnosis of possible restenosis (Eisenberg et al., 2001; Babapulle et al., 2007). A standard method in CHD diagnostics and follow-up is an exercise test, which remains the most available and cost effective diagnostic opportunity (Kligfield and Okin, 1994; Kligfield and Lauer, 2006). Even though the clinical value of solitary exercise test nowadays is limited (Gianrossi et al., 1989), our observations showed that focussed exercise test programmes could be useful in early diagnosis of restenosis. 
From the very beginning after introduction of interventional treatment in coronary artery disease in the Latvian Centre of Cardiology, a specific follow-up programme with consecutive aims was developed:

1) to evaluate functional status of patients after interventional treatment, possible risks of further cardiovascular events and effectiveness of actual treatment;

2) to develop a prognostic model that can identify patients with unfavourable long-term prognosis or inadequate interventional treatment results;

3) to identify a patient data set to analyse specific subgroups of patients at different risk of further cardiovascular events.

\section{MATERIALS AND METHODS}

The exercise tests investigation of 7,300 patients were analysed from the year 2006 till 2008. Patients were inspected $1-3 ; 3-6,6-12$ and $12-24$ months after interventional treatment by a physical stress test to evaluate possible risk of restenosis and to perform adequate corrections in medications. We used a bicycle test with standardised protocol developed in the Latvian Centre of Cardiology, which excluded inter-operator influence on results and determination of formulation variability. We assumed that the exercise test was positive if in electrocardiogram (ECG) appeared horizontal or downward sloping ST-segment depression or elevation $\geq 1 \mathrm{~mm}$ up to $60 \mathrm{~ms}$ after the QRS, in particular when ECG changes were accompanied with typical chest pain at loud of 75 Watt and lower and continued more than 3 min after end of the load (Mintāle and Ērglis, 2008). We analysed also haemodynamic parameters - maximal heart rate, systolic blood pressure, Robinson index (RI), total exercise time, chronotropic competence as well as subjective data - exercise induced angina pectoris, exercise limiting symptoms and time interval to the beginning of angina pectoris.

In the framework of the follow-up programme, analyses of drug therapies were conducted for 3,200 patients at three, six and twelve months after interventional treatment. The control group consisted of 382 patients without a focussed follow-up programme. For the control group patients a drug therapy check was performed twelve months after percutaneous coronary intervention (PCI). Adequate corrections in drug therapy and risk factor control were made depending on exercise test results.

The Latvian Society of Cardiology recommendations on stable angina pectoris (Erglis et al., 2007) have set goals for use of appropriate drug therapies, which include antiplatelets, lipid lowering drugs, angiotensin-converting enzyme (ACE) inhibitors and angiotensin II receptor blockers (ARB), $\beta$-blockers and calcium channel blockers.

The aim of the programme was not only to evaluate functional status of patients after interventional treatment but to assess treatment efficacy and to perform changes in medica- tions depending on data received in exercise test. Therefore, we analysed the used drug groups. Separate analyses were made in high risk patients with left main (LM) disease. SPSS 12.0.1. version was used for statistical analyses. Baseline characteristics were summarised as frequencies and percentages for categorical variables and as means and SDs for continuous variables. Analyses were performed using the Student $t$ test/ANOVA method for continuous variables. Differences were considered statistically significant at $P<$ 0.05 .

\section{RESULTS}

Serious complications such as myocardial infarction, life threatening arrhythmias or death did not appear during the exercise test. Coronary complaints were admitted by 1,226 (16.8\%) patients and ischemic ST-segment changes were documented in $975(13.4 \%)$ patients. Generally, from whole study group angiographic diagnosis of restenosis was diagnosed in $470(6.4 \%)$ patients (Fig. 1).

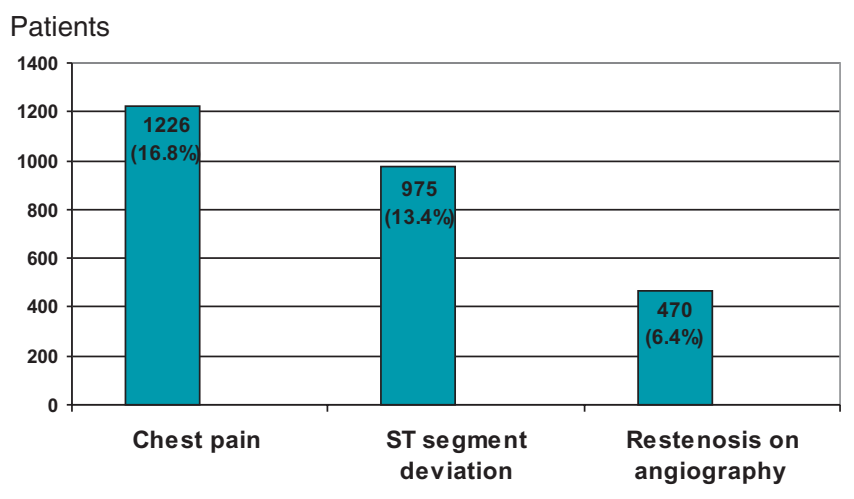

Fig. 1. Total exercise test results.

During follow-up visits, we identified a special patient subgroup (22\% - 1,606 patients) without chest pain but with a significant shift of the ST-segment in ECG during physical loading. This is called silent ischemia and is connected with unfavourable prognosis (unstable angina, myocardial infarction, cardiac death). Relevant restenosis on angiography was established in 658 (41\%) patients with silent ischemia, which amounts to $9 \%$ of all patients. The large proportion of patients with silent ischemia demonstrates the necessity of a focused follow-up programme instead of complaint based indication for the exercise test.

Patients with a focussed follow-up programme almost achieved drug therapy goals set by national guidelines (Fig. 2 ). The reported use of drug therapies 12 months after PCI in control group patients significantly decreased. Reduction in use of aspirin, statins, $\beta$-blockers, ACE-inhibitors, clopidogrel and $\mathrm{Ca}$ channel blockers was recorded in $12 \%$, $16 \%, 5 \%, 11 \%, 29 \%$ and $33 \%$, respectively (Fig. 3). The majority of dose corrections were made 3-6 months after intervention for adequate blood pressure control (for $46 \%$ of patients) and 6-12 months after PCI for achievement of cholesterol targets (for $72 \%$ of patients). 

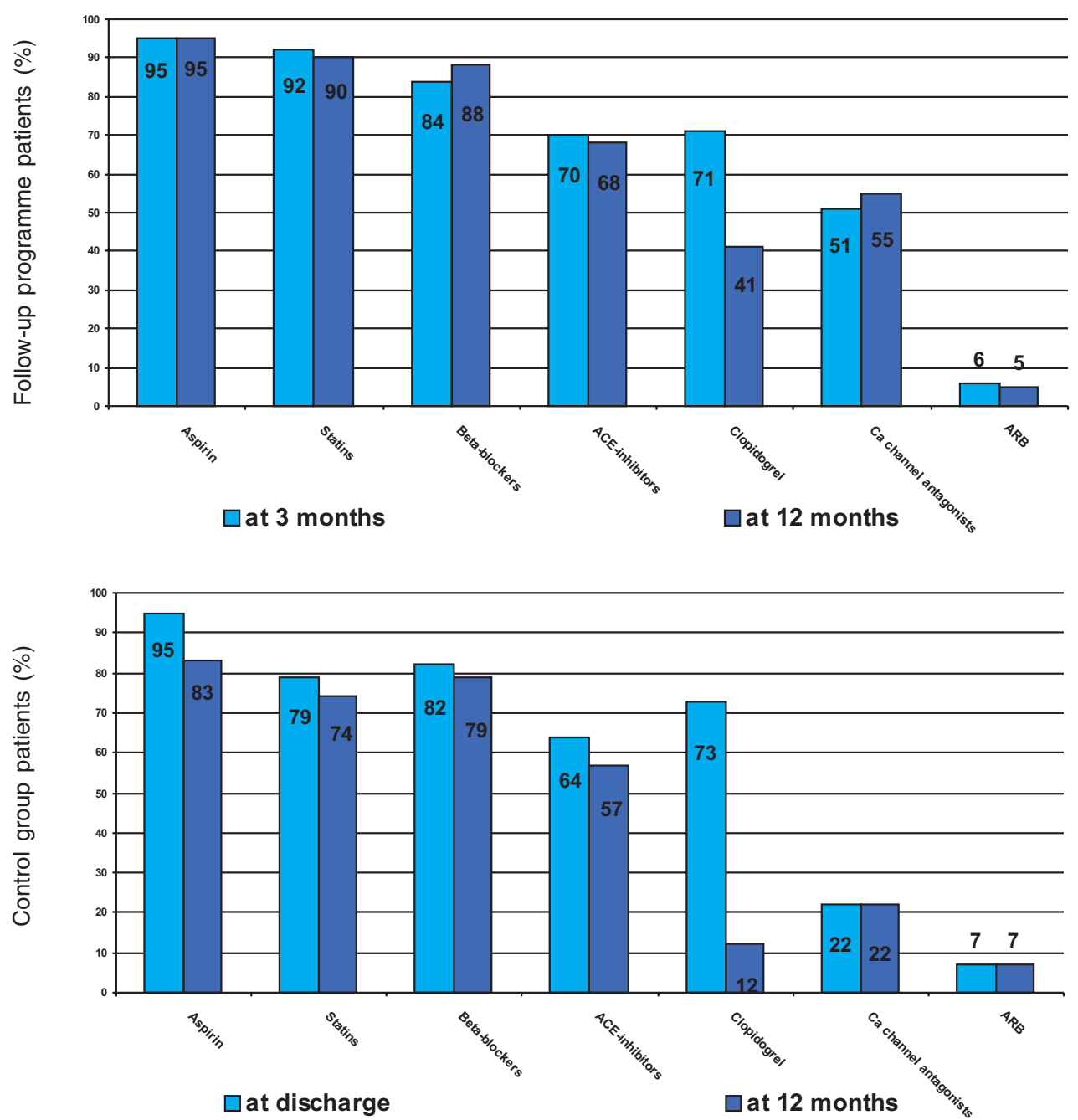

Fig. 2. Drug therapy analyses for follow-up programme patients.
Fig. 3. Drug therapy analyses for control group patients.
Separate analyses were conducted for high risk patients with LM disease after successful interventional treatment with implantation of drug eluting stents. In those patients $50 \%$ of all restenosis were diagnosed early (3 to 6 months after PCI), $47 \%$ in the time interval between 6 to 12 and the others $7 \%$ twelve to 24 months after PCI. In the early exercise test follow-up visit (one to three months after PCI) documented ischemic changes on ECG correlated tightly with angiographic results at 1-3 months after PCI. Each restenosis documented on angiography was accompanied with ST-segment depression on exercise ECG. The calculated specificity was $100 \%$ and sensitivity $29 \%$ for the exercise test at early follow-up (1-3 months after PCI). In this subgroup a lower RI was registered. The follow-up results at 3-6 months after PCI showed a ST-segment shift correlation with angiographic restenosis. Calculated specificity was $86 \%$ and sensitivity $50 \%$. Every patient with newly developed lesions in other coronary vessels documented on angiography 3-6 months after PCI had ST-segment depression at early follow-up. However, for patients without stenosis on angiography in $92.9 \%$ of cases ST-segment changes on exercise ECG were not documented. This corresponds to a sensitivity of $33 \%$ and specificity of $93 \%$.

Patients with restenosis achieved less physical loading at exercise test because of test termination without reaching submaximal heart rate according to shift of the ST-segment. This could explain the differences in RI curves for patients with and without restenosis. However, there were no statistical differences in maximal heart rate and systolic blood pressure between patients with and without restenosis (Table 1). For patients with restenosis the RI showed a significant decrease at 3-6 months after intervention (209.80 \pm 59.58 in comparison with $226.19 \pm 60.01$ at early visit) (Table 2). In contrast, for patients without restenosis, the RI demonstrated a significant increase from $210.79 \pm 52.90$ (1-3 months after PCI) to $225.03 \pm 46.41$ (3-6 months after PCI) and at 6-12 months after PCI reached a plateau $(222.00 \pm 47.44)$ (Table 3). Although there was no statistical significance $(P>0.05)$, a graphical trend is evident (Fig. 4).

\section{DISCUSSION}

In this study we raised the question whether physical exercise test alone beside accurate diagnosis of obstructive lesions provides an opportunity to prognose cardiovascular risk. We claim that this is possible, which is demonstrated in our study by a significant number of patients with silent ischemia. The potential gain from reducing the risk of reverse cardiac events is actually greatest in those with silent ischemia at the time of follow-up presentation, because 
MEAN VALUES OF ANALYSED PARAMETERS DURING EXERCISE TEST FOLLOW-UPS

\begin{tabular}{|c|c|c|c|c|c|}
\hline Exercise test data/ Follow-up visit & 1-3 months & 3-6 months & 6-12 months & 12-24 months & 24 months \\
\hline Maximal pulse under exercise \pm SD & $118 \pm 16$ & $122 \pm 17$ & $121 \pm 16$ & $119 \pm 15$ & $119 \pm 15$ \\
\hline Maximal systolic blood pressure under exercise, $\mathrm{mmHg} \pm \mathrm{SD}$ & $180 \pm 31$ & $181 \pm 29$ & $182 \pm 29$ & $183 \pm 31$ & $184 \pm 32$ \\
\hline
\end{tabular}

Table 2

Table 3

ROBINSON INDEX AT DIFFERENT FOLLOW-UP VISITS FOR PATIENTS WITH RESTENOSIS

\begin{tabular}{lcccc}
\hline & RI at 1-3 months & RI at 3-6 months & RI at 6-12 months \\
\hline Mean & 226.19 & 209.80 & 211.96 \\
Median & 226.19 & 179.00 & 227.50 \\
Std. deviation & 60.01 & 59.58 & 44.26 \\
Minimum & 183.75 & 141.10 & 146.00 \\
Maximum & 268.62 & 297.44 & 256.51
\end{tabular}

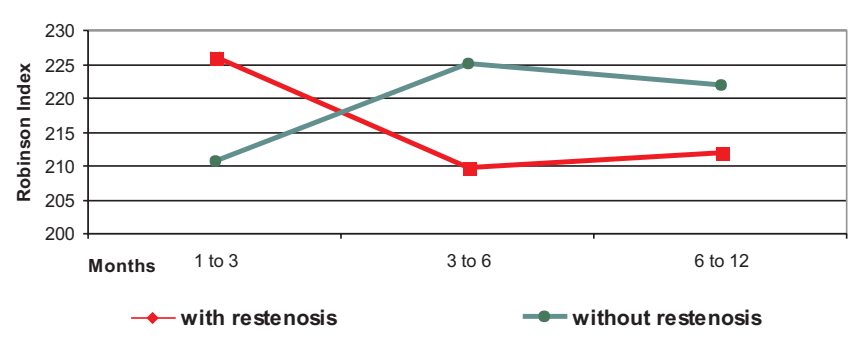

Fig. 4. Robinson Index at different follow-up visits for patients with and without restenosis.

those patients are at especially high risk (Pepine and Deedwania, 1994). Nowadays it is clear that chest pain in history does not correlate tightly with ischemic ST-segment deviation following physical loading and with haemodynamically significant stenosis on angiography either.

Published data as well as national and international guidelines state that physical exercise test following PCI is a useful method in diagnosis of restenosis in high risk or symptomatic patients and should be conducted six months after intervention (Gibbons et al., 2002). Our results showed that the exercise test should be done not later than three to six months after intervention. The highest rate of restenosis was observed in $50 \%$ of patients after interventional treatment of LM disease and in $45.8 \%$ for other lesion localisations calculated from all documented cases of restenosis. The importance of the physical test does not decrease later; $37.5 \%$ of all documented restenosis were registered at six months after intervention (including $50 \%$ of patients with newly diagnosed stenosis on angiography). One year after PCI the specific weight of restenosis was $16.7 \%$ of all diagnosed restenosis.

The clinical value of exercise electrocardiograms following interventional therapy in the early period is high in evaluation of early post-interventional results (Roffi et al., 2003). This is supported with our results, which demonstrated specificity of $100 \%$ of exercise test performed in the first six months after PCI. Exercise electrocardiograms 1-3
ROBINSON INDEX AT DIFFERENT FOLLOW-UP VISITS FOR PATIENTS WITHOUT RESTENOSIS

\begin{tabular}{lcc|cc}
\hline & RI at $1-3$ months & RI at $3-6$ months & RI at 6-12 months \\
\hline Mean & 210.79 & 225.03 & 222.00 \\
Median & 218.85 & 234.08 & 220.02 \\
Std. deviation & 52.90 & 46.41 & 47.44 \\
Minimum & 110.20 & 114.40 & 105.91 \\
Maximum & 318.20 & 299.52 & 308.14
\end{tabular}

months after PCI did not show a shift of the ST-segment for all patients without restenosis. However, ECG of the ST-segment was registered on exercise ECG only for patients with restenosis. This demonstrates a clear correlation between ST-segment depression and restenosis. Generally, shift of the ST-segment following physical loading was documented in $60 \%$ of patients with restenosis on angiography while in $90.5 \%$ of patients with normal exercise electrocardiograms restenosis in coronary vessels was not found.

Adequate implementation of drug therapies depending on patient clinical and functional status allow to reach goals set by national and international guidelines. Based on epidemiological studies, even small decreases in low density lipoprotein cholesterol and blood pressure levels translate into significant reductions in cardiovascular morbidity and mortality (LaRosa et al., 2005). Moreover, especially important is the patient compliance, which can be achieved through frequently scheduled visits.

The clinical course and prognosis of patients with CHD can be modified favourably by successful translation of recommendations for secondary coronary prevention into effective clinical care. Crucial to the outcome of any preventive strategy is patient attitude to lifestyle modification and compliance with drug therapies over the long term. We tend to claim that an aggressive follow-up programme could help us to reach the goals in secondary prevention of CHD set by European Societies and Latvian Society of Cardiology.

The physical exercise test is a safe method with high specificity but is limited by poor test sensitivity for the evaluation of efficacy of interventional and drug treatment for patients with CHD. A focussed exercise test given on a regular basis indirectly influences clinical results and prognosis. Timely set diagnosis of restenosis provide necessary treatment measures, therefore, alienating reverse cardiac events such as unstable angina and myocardial infarction. Moreover, an exercise test performed on a regular basis provides essential corrections in drug therapy. After comparison of 
drug therapies recommended three months and one year after PCI, we can conclude that regular follow-ups provide the opportunity to sustain acceptable patient compliance and use of medications even twelve months after an intervention.

A focussed follow-up programme with an exercise test allows to evaluate clinical status of patients as well as to determine timely possible risk of restenosis, to adapt medication doses, to reduce risk factors and to influence positively patient compliance. The exercise test provides accurate estimation of possible restenosis in patients with complete revascularisation. In patients with incomplete revascularisation the exercise test specificity is reduced. Taking into account the results of the current study, we are sure that focussed physical exercise test should be advised for all patients after interventional treatment. It is of high importance to achieve submaximal heart rate during the exercise test. In all cases when this is not possible for any reason, myocardial perfusion scintigraphy is indicated.

\section{ACKNOWLEDGEMENT}

The work was supported by the National Research Programme in Medicine 2006-2009, project No. 1, „Elaboration of new methods of early diagnostics, prevention and treatment of cardiovascular diseases".

\section{REFERENCES}

Babapulle, M., Diodati, J., Blankenship, J., Huynh, T., Cugno, S., Puri, R., Nguyen, P., Eisenberg, M. (2007). Utility of routine exercise treadmill testing early after percutaneous coronary intervention. BMC Cardiovascular Disorders, 7, 12 .

Bengtson, J., Mark, D., Honan, M., et al. (1990). Detection of restenosis after elective percutaneous transluminal coronary angioplasty using the exercise treadmill test. Amer. J. Cardiol., 65, 28-34.

Eisenberg, M., Schechter, D., Lefkovits, J., Goudreau, E., Deligonul, U., Mak, K., Del Core, M., Duerr, R., Garzon, P., Huynh, T., Smilovitch, M., Sedlis, S., Brown, D., Brieger, D., Pilote, L. (2001). ROSETTA Investigators: Use of routine functional testing after percutaneous transluminal coro- nary angioplasty: Results from the ROSETTA Registry. Amer. Heart J., 141, 837-846.

Ērglis, A., Kalvelis, A., Jirgensons, J., Zakke, I., Mintāle, I., Narbute, I., Keiša, M. (2007). Latvijas Kardiologu biedrības darba grupa. Stabilas stenokardijas vadlinijas [The guidelines of the Latvian Society of Cardiology on prevention and management of stable coronary heart disease]. Rīga. 97 lpp.

Fletcher, G., Balady, G., Froelicher, V., Hartley, L., Haskell, W., Pollock, M. (1995). Exercise Standards. A Statement for Healthcare Professionals from the American Heart Association. Writing Group. Circulation, 91, 580-615.

Gianrossi, R., Detrano, R., Mulvihill, D., Lehmann, K., Dubach, P., Colombo, A., McArthur, D., Froelicher, V. (1989). Exercise induced ST depression in the diagnosis of coronary artery disease: A meta-analysis. Circulation, 80, 87-98.

Gibbons, R., Balady, G., Bricker, J., Chaitman, B., Fletcher, G., Froelicher, V., Mark, D., McCallister, B., Mooss, A., O'Reilly, M., Winters, W. (2002). ACC/AHA 2002 Guideline Update for Exercise Testing. A Report of the American College of Cardiology/ American Heart Association Task Force on Practice Guidelines (Committee on Exercise Testing). ACC/AHA Practice Guidelines.

Kligfield, P., Lauer, M. (2006). Exercise electrocardiogram testing. Beyond the ST segment. Circulation, 114, 2070-2082.

Kligfield, P., Okin, P. (1994). Evolution of the exercise electrocardiogram. Amer. J. Cardiol., 73, 1209-1211.

LaRosa, J., Grundy, S., Waters, D., Shear, C., Barter, P., Fruchart, J., Gotto, A., Greten, H., Kastelein, J., Shepherd, J., Wenger, N. (2005). Intensive lipid lowering with atorvastatin in patients with stable coronary disease. New Eng. J. Med., 352, 1425-1435.

Libby, P., Theroux, P. (2005). Pathophysiology of coronary artery disease. Circulation, 111, 3481-3488.

Mintāle, I., Ērglis, A. (2008). Fiziskās slodzes testi. Metodiskie norādījumi [Recommendations of the Latvian Society of Cardiology on physical exercise tests]. Latvijas Kardiologu biedrība. Rīga, 48 lpp

Pepine, CJ., Cohn, P.F., Deedwania, P.C., Gibson, R.S., Handberg, E., Hill, J.A., Miller, E., Marks, R.G., Thadani, U. (1994). Effects of treatment on outcome in mildly symptomatic patients with ischemia during daily life: The atenolol silent ischemia study (ASIST). Circulation, 90,762-768.

Roffi, M., Wenaweser, P., Windecker, S., Mehta, H., Eberli, F., Seiler, C., Fleisch, M., Garachemani, A., Pedrazzini, G., Hess, O., Meier, B. (2003). Early exercise test after coronary stenting is safe. J. Amer. Coll. Cardiol., 42, 1569-1573.

Ruygrok, P., Webster, M., De Valk, V., van Es, G., Ormiston, J. (2001). Clinical and angiographic factors associated with asymptomatic restenosis after percutaneous coronary intervention. Circulation, 104, 2289-2294.

Received 11 July 2009

\section{MĒRKTIECİGAS SLODZES TESTA APSEKOŠANAS PROGRAMMAS NOZĪME KORONĀRĀS SIRDS SLIMĪBAS PACIENTIEM, ĀRSTÉTIEM AR PERKUTĀNU KORONĀRU INTERVENCI}

Koronāro sirds slimību (KSS) ārstēšanas pamatā ir koronāro asinsvadu lūmena atjaunošana, ko veic ar invazīvu metodi - perkutānu koronāru intervenci (PKI), kombinējot to ar medikamentozu terapiju. Lai optimizētu šādu pacientu aprūpi un ārstēšanu, Latvijas Kardioloǵijas centrā tika izveidota plānota pacientu apsekošanas programma, kuras galvenais izmeklējums ir slodzes tests. Latvijā līdz šim nav veikts šāds pētījums, kas sniegtu plašas iespējas analizēt pacientu funkcionālo stāvokli, lietotās ārstēšanas efektivitāti, iespējamo risku un prognozi pēc invazivvas KSS ārstēšanas. Izveidots PKI pacientu datu reğistrs. Slodzes tests joprojām ir KSS diagnostikas pamatmetode. Tāpat šo metodi lieto, lai noteiktu iespējamu restenozi koronārajās artērijās - procesu, kas ir patofizioloğiski atšḳirīgs no primāra aterosklerozes mehānisma (atpakalı̆saraušanās, vēlīna remodelācija, tromboze, neointīmas proliferācija). Mērķtiecīgi apsekoti 7300 pacienti ar KSS, kas ārstēti ar PKI (laikā no 2006. līdz 2008. gadam), izdarot slodzes testu. Apsekošana veikta 1-3, 3-6, 6-12 mēnešus pēc koronāras intervences. Veikta lietoto medikamentu grupu analīze. Atsevišķi apskatīti īpaši augsta riska pacienti ar kreisās koronārās artērijas stumbra $(L M)$ stenozi. Analizēts pacientu klīniskais un funkcionālais stāvoklis, prognozēta restenozes iespējamība, koriǵéti medikamenti, plānoti nepieciešamie izmeklējumi un izmainas ārstēšanas plānā. Pēc indikācijām veikta kontroles angiogrāfija. Apsekoto KSS pacientu grupā 17\% pacientiem ir koronāras sūdzības, $13 \%$ konstatētas nozīmīgas ST segmenta izmaiņas elektrokardiogrammā slodzes testa laikā, 6,4\% no šiem pacientiem angiogrāfiski noteikta restenoze koronārajos asinsvados. Gandrīz pusei šo pacientu (46\% gadījumu) restenozi konstatē agrīnā periodā (3-6 mēn. pēc PKI). Atrasta pacientu grupa ar pozitīvu slodzes testu, bet bez sūdzībām („,klusā išēmija”) - 22\% pacientu, no kuriem $41 \%$ konstatē restenozi (t.i., $9 \%$ no kopējā pacientu skaita). Arī $L M$ pacientiem 50\% restenožu gadījumus konstatē agrīnā periodā (3-6 mēnešus pēc PKI), pārējos 43\% - 6-12 mēn. un 7\% 12-24 mēn. pēc PKI. Agrīno restenožu pacientiem angiogrāfiskie rezultāti korelē ar ST segmenta išēmiskām izmaiņām EKG slodzes testa laikā, kā arī reǵistrēts zemāks Robinsona indekss. Mērḳtiecīga apsekošanas programma, veicot slodzes testu, ḷauj novērtēt pacientu klīnisko stāvokli, savlaicīgi noteikt iespējamo restenozes risku, precīzi dozēt nepieciešamos medikamentus atkarībā no pacienta funkcionālā stāvokḷ, koriğêt riska faktorus, kas varētu nelabvēlīgi ietekmēt slimības gaitu, kā arī nodrošināt augstu pacientu līdzestību. 